\title{
Participative Budgeting Reality in The Society of Osing Ethnic Kemiren Village Banyuwangi District (An Ethnometodology Study)
}

\author{
Shofyan Hadi \\ Magister Program of Economics and Business Faculty, Jember University-Indonesia \\ Siti Maria Wardayati \\ Economics and Business Faculty, Jember University-Indonesia \\ Muhammad Miqdad \\ Economics and Business Faculty, Jember University-Indonesia
}

\begin{abstract}
The purpose of this study was to find out, analyze and provide an overview of the reality of the life of the osing society of Kemiren Banyuwangi Village, especially regarding involvement in the budgeting planning process. This research is classified into qualitative research with the approach used in this research is ethnometodology approach. Broadly speaking, the results of this research explain that the Osing ethnic in Kemiren Village, Glagah Sub-district has local wisdom that until now is still very maintained. The exclusion of local wisdom values found in the ethnic of osing in the form of mutual cooperation, honesty, mutual or harmonious values, obedience values or accordingly all represent representation of the osing society in behaving and will influence the development process.
\end{abstract}

Keynote: Osing Ethnic, Local Wisdom, Budgeting,Ethnometodology

DOI: $10.7176 /$ RJFA/11-2-14

Publication date: January $31^{\text {st }} 2020$

\section{Introduction}

Accounting is an activity to provide financial information that is used to make economic decisions (Sulistiawan, Januarsi, Alvia 2011: 4). As long as economic activity still uses money in transactions, the role of accounting is still very much needed to record financial economic transactions (Warsono, Darmawan, Ridha, 2009: 2). At present accounting with applicable standards is a tool used by management with the help of accountants to compile and present financial statements. Accounting practices in business organizations are certainly inseparable from the policies given by management in choosing procedures or methods that will be used in organizations that are appropriate and allowed by standards (Arif, Aulia, Herawati, 2014). The existence of generally accepted accounting principles also provides convenience and flexibility for managers to choose accounting procedures and methods to be used in preparing financial statements (Sulistiawan, 2006).

There is a new perspective based on Law No. 23 of 2014 concerning Regional Government, in the process of drafting the Regional Budget (APBD) it requires community involvement and budget transparency in all budget cycles. Sopanah (2004) explains that doing this will strengthen control in the process of budgeting and implementation. The consequence of the existence of these regulations is that the community can be directly involved in both the planning process, the implementation process and the accountability process. Given the importance of community involvement, appropriate steps are needed so that community involvement can run conducively (Hasan and Bahri, 2016). The results of research conducted by Sopanah $(2007,2008,2009)$ show that although community involvement in the budgeting process is regulated in legislation, the reality is that community involvement in the local budgeting process is still not effective, and community involvement in the budget planning process is still low and only limited to attendance.

Budgeting is a fairly difficult process in public sector entities, especially in government, including among them the village government (Widyaningsih, 2011). In this case there are differences in terms of budgeting in the private sector. If in the private or private sector the budget is a secret of a business entity that is closed to the public, but on the contrary in the public sector the budget must be submitted to the public to be given input and criticism. Budgeting in public sector entities is the most complicated stage and contains many high political elements. The budgeting process is actually the decisive stage in allocating funds and resources. Widyaningsih (2011) explained that the existence of various kinds of interests and needs as well as the limited availability of funds would require a mindset that is able to change the general direction and policies that have been formulated in the form of work programs and strategies, both long and short term strategies. 
Planning and budgeting is important from the process of determining policies in the framework of implementing governance and development, so the results of planning are budgeting (Widyaningsih, 2011). Law Number 25 of 2004 concerning the National Development Planning System (SPPN) mandates that, SPPN is an integrated set of procedures for long-term, medium-term and annual development planning carried out by state and community administrators at the central and regional levels. All aspirations delivered are included in a development planning deliberation activity, which will produce development policy documents, such as the Regional Long Term Development Plan (RPJPD), Regional Medium-Term Development Plans (RPJMD) and Regional Government Work Plans (RKPD).

This also applies to financial management systems at the village level. As explained in Law No. 6 of 2014 Chapter VIII Article 71 - 75 concerning village finance and assets, Government Regulation No. 43 of 2014 Chapter VI Articles 90 - 105 concerning village finance, allocation sourced from APBN and APBD, distribution, village expenditure, APBDes, reporting \& liability, Government Regulation No. 60 of 2014 and Government Regulation No. 22 of 2015 concerning changes to Government Regulation No. 60 of 2014 concerning Village Funds sourced from the State Budget, Permendagri No. 113 of 2014 concerning Village Financial Management. The term village is usually synonymous with the conditions of traditional, poor and conservative societies (Furqaini, Astri, 2011). However, Junita (2016) explained that the village is an area inhabited by a number of indigenous people and has a government that has been arranged in accordance with the agreed rules. So in this case the village in preparing the Village Budget (APBDes) also needs to develop a Village Medium-Term Development Plan (RPJMDes) and also after making the RPJMDes the Village needs to also develop a Village Development Work Plan (RPKPDes) which then becomes the basis in the determination of the APBDes (www.keuangandesa.com).

The Osing ethnic community in Banyuwangi Regency is known to be very strong in appreciating its rituals and arts, even more when compared to other ethnic groups in Banyuwangi (Anoegrajekti, 2015). The Osing ethnic has a lot of unique traditions, arts and culture and is full of magic (Hasan and Bahri, 2016). Arts The Osing ethnic has a variety of cultural patterns, this is because in the arts osing ethnic much influenced by Bali, besides that the style of art is also influenced by Madura and Europe. The Osing ethnic is very upholding cultural values such as mutual cooperation, voluntary work, social gathering and hospitality. The community of osing ethnic Kemiren Village, Glagah Banyuwangi District, has many unique traditions and rituals that are still preserved today. There are several traditions of the osing ethnic that are already popular, namely barong ider bumi, tumpeng sewu, and mepe kasur. In addition there are many other traditions such as chewing sirih, mudun lemah, koloan, kawin colong, arak-arakan tradition, ngopi sepuluh ewu and others. Almost all the arts produced by osing communities in the area are appreciated by the Osing community (Anoegrajekti, 2015). This fact is always conveyed by many researchers and writers regarding rituals and arts in Banyuwangi, such as Scholte (1927), Sujadi (1986), Murgianto and Munardi (1990), Puspito (1990), Wolbers (1992, 1993), and Anoegrajekti (2004, 2006, 2010, 2014) this was formed since the 19 th century and was very lively at the end of the 50 s until now.

The village financial report is a form of transparency needs which is a supporting requirement for accountability in the form of openness of the village government over the management of public resources (Hanifa and Praptoyo, 2015). Explained by Widyaningsih (2011) that how the concept of budgeting itself is in the context of government organizations and how it relates to various existing regulations and policies, especially in relation to regional autonomy which is then identical to fiscal decentralization, the budget in Local Government needs to be understood in an integrated manner. This then needs to be reviewed from the paradigm of the whole process and things that become influential factors. The budget is understood as a planning tool in which it contains an activity plan consisting of a number of targets to be achieved.

The application of local values in the budgeting process can be done in a non-formal way that comes from innovative initiatives from the community itself, this is actually more effective than formal processes such as musrenbang. Realities that occur in everyday life indicate that although community involvement in the development and planning of regional budgeting is considered very important. Cooper and Elliot (2000), Navaro (2002), Laurian and Adam (2004) explain that community involvement is still very low. The low level of involvement is due to the rare presence in public meetings, public meetings are considered to be still less effective as a means of rational persuasion, but public meeting is useful for maintaining a local democratic system (Laurian and Adam, 2004).

The purpose of this study was to find out, analyze and provide an overview of the reality of the life of the osing ethnic community in Kemiren Banyuwangi Village, especially regarding involvement in the budget planning process.

\section{Theoretical Foundation \\ 2.1. Budgeting Definition}

The budget in the public sector is an instrument of accountability in the management of public funds and the implementation of activities financed with public money in terms of regional autonomy (Sugiartha et al, 
2014). The budget is a financial plan that is prepared for the activities that have been ratified or a written plan of an activity in an organization that is expressed quantitatively and generally presented in units of money for a certain period of time (Nafarin, 2000, Handayani, Arianti, 2010, Sugiartha et a, 12014, Astuti et al, 2017). Garrison and Noreen (2006) explained that the budget is a detailed plan about the acquisition and use of financial resources and other resources for a given period. Budget is also a financial plan usually the budget period is one year and is a tool - a tool for control and short-term planning (Anthony and Govindarajan, 2005: 90).

If we can conclude the public sector budget is a plan of activities created and used by the government, both the central government and regional governments expressed in financial measures, which contain information about income, expenditure, activities, and financing in monetary units. Principles - budget principles in public sector organizations according to Mardiasmo (2004) are: authority by the legislature, comprehensive, budget integrity, non-discretionary appropriation, periodic, accurate, clear, and known by the public.

\subsection{Participatory Budgeting}

Participatory budgeting is the process of planning activities involving the community or individuals and having an influence in determining the objectives of a performing budget that will be evaluated and rewarded for the success of their budget (Brownel, 1982). Participatory budgeting is also a creative innovation in determining policies - in this case involving the community directly in determining policies (Usman \& Paranoan, 2013). So from that participatory budget is a process in an institution or agency that involves various parties in determining the objectives of the budget that are their responsibility.

The method of participation is a good method of budgeting, where all components in an entity or organization are involved in budget preparation (Garrison et al, 2006). Participatory budgeting is one way to make good management control, so that government employees or the public involved in the budgeting process are given the opportunity to be part of decision making in budget planning (Zein, 2016).

\subsection{Budgeting Planning}

Planning is an important part of a government entity. Good planning will produce good performance too. Firmansyah (2012) explained that village financial planning is an activity carried out by the village government together with the village community in making village financial planning in the context of implementing village development. Explained in Law No. 6 of 2014 concerning villages article 73 paragraph 2 states that "The Village Budget and Expenditure Budget Plan was proposed by the village head and discussed with the Village Consultative Body".

\subsection{Budgeting Implementation}

The implementation of the village budget has been stipulated in the planning which previously arose village receipt and disbursement transactions in the context of village implementation carried out through village accounts. All village receipts and expenses must be accompanied by valid transaction proof.

There are several rules in implementing village financial management: 1) All village receipts and expenditures in the framework of implementing village authority are carried out through village accounts. 2). All village receipts and expenses must be supported by complete and legal evidence. 3). The use of unexpected costs must first be made into a detailed budget that has been approved by the village head. 4). Treasurer must account for money through accountability reports. 5). The village treasurer must account for money through the accountability report. 6). The accountability report as referred to in paragraph 5 is submitted every month to the village head and no later than the 10th of the following month

\subsection{Responsibility}

The accountability report for the realization of APBDes consists of income, expenditure, and financing. The report sets out village regulations and attaches the attachments as follows: 1). Format of accountability report realization of APBDes.2) Format of report on village property as of December 31 of the budget year. 3). Format of government and regional government programs that enter the village.

\subsection{Society Participation in Budgeting Planning}

Participatory budgeting is an important activity and involves various kinds of parties who have authority in budgeting to prepare and evaluate various choices of solutions and objectives of the budget (Wulandari, and Riharjo, 2016). Participation or involvement is defined by Mulyadi (2001) as a process for making joint decisions by several parties that have a direct impact on decision makers in the future. In addition, Brownell (1982) explains participatory budgeting is a process where individuals are involved in it and have an influence on the preparation of budgets whose performance will be evaluated and may be rewarded. Whereas Soleman (2012) defines participatory budgeting as the participation or involvement of managers in the budgeting process including decision making.

Budgets in public sector entities are made to determine community needs, direct social and economic developments that will affect the improvement of people's welfare (Wulandari, and Riharjo, 2016). In the context of policy, resource allocation decisions for various needs in the form of expenditure each year are reflected in the APBN, APBD, and even the APBDes. In reality, budget practices cannot be separated from the interests that must be included and at the same time become the mediation of various community needs. If it is interpreted broadly, 
the budget has a distributive function, which means that a budget must pay attention to the sense of justice and propriety (Hasan and Bahri, 2016).

Table 2.1 describes the Eight society participation that occurs in each region has certain characteristics depending on the environmental, economic, cultural and political characteristics that occur in the area. Arnstein (1971) explained the Ladder of Participation theory where community power influences changes in policy making. In the theory of participation ladder there are three levels of participation which are then broken down into eight steps of participation. The lowest level of participation is no participation consisting of two steps, namely manipulation and therapy. Participation activities that occur at this level are in reality distortions of participation and only allow power holders to simply educate and please participation. Clearly the eight steps of Arstein's participation (1971: 4) are explained in the following table:

Ladder of articipation

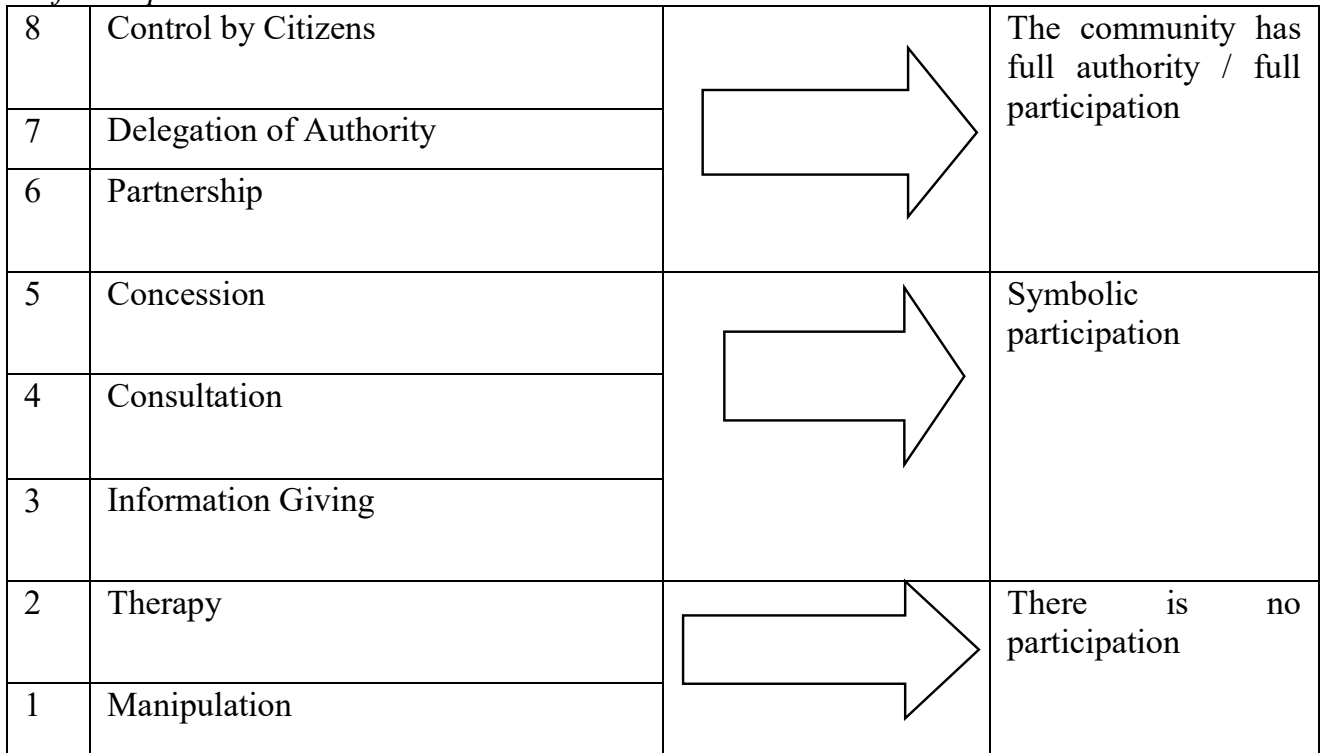

Sources: Arnstein (1970)

\subsection{Local wisdom}

Local wisdom which often means local knowledge, local intelligence and local policies, by the Republic of Indonesia Law No. 32 of 2009 concerning Protection and Management of the Environment is defined as the noble values that apply in the life order of the society which among others are used to protect and manage the environment live sustainably. The Osing people who live in Kemiren Village are a group of people who have different social and life strata from Indonesian society in general. In the face of changes caused by modernization and globalization, the Osing community made adjustments by not abandoning the value of existing local wisdom. Communication and interaction between fellow human beings who have a goal to maintain and carry on traditions, ideas, goals, real identity, values in thinking and feelings, attitudes, and behaviors that they have resulted in the system of tribal communities still maintain all the rules, and ways his view of the long-standing social system side by side with their existence (Hasan and Bahri, 2016).

In general, we can find wisdom - local wisdom in the proverb, sasanti, nyayian, slogan, advice, and ancient books that are inherent in daily activities. The description of local wisdom can usually be seen in longterm society group life habits. Continuity of local wisdom will be reflected in the values that apply in a particular group society. These values become the grip of certain society communities which usually will become part of an inseparable life, this can be seen through their behavior and attitudes everyday. This sedimentation process requires a very long time, from one generation to the next. The emergence of local wisdom in the society is the result of a trial and error process of various types of empirical and non-empirical knowledge or beautiful and intuitive.

The form of local wisdom can be categorized into two aspects, namely the first tangible, for example there are several kinds of local wisdom such as procedures, value systems, special provisions as outlined in written notes such as those found in traditional primbon books, calendars and prasi. The second is intangible, for example, the advice delivered verbally and downward can be in the form of songs and songs that have traditional teaching values. Through advice or other forms of intangible local wisdom, social values are conveyed orally / verbally for generations (Hasan and Bahri, 2016, Sopanah, 2016). 


\section{Reseacrh Method}

\subsection{Types of research}

The type of research used in this study is qualitative research. Qualitative research explained by Moleong (2015: 6) is intended to provide an understanding of events relating to what is experienced by the subjects studied such as holistic, actions, motivations, behaviors, etc. in the form of words and language, in a special natural context and utilizing various natural methods. The approach used in this research is ethnometodology approach. Ethnometodology is the study of the meaning of a phenomenon of human actions within the community / ethnic / group (Fatchan, 2015: 88). Prasetyo (2012) explains that Ethnometodology is empirical research to analyze general beliefs and behavior as a basic aspect of all behavior and actualization.

Muhadjir (2000: 145) explains in order to follow ethnometodology principles it is important to focus on aspects of indexicality and reflectionality which are important concepts in ethnometodology. Indexicality refers to every effort related to the meaning of words, behavior and others in their context, while reflectionality refers to any effort in regulating the relationship between events / phenomena and other events / phenomena (Ludigdo 2006).

\subsection{Research Social Sites and Informants}

This research was conducted on the people of the Osing ethnic, Kemiren Village, Glagah District, Banyuwangi Regency. Ethnometodology as a research approach that wants to uncover social phenomena is needed by key informants who will provide data, information, experience and others to answer research problems. Informants in this study were the customary leader, village apparatus, religious leaders, and village society.

\subsection{Data Collection and Analysis Method}

The interview used in the interview is in-depth. According to Bungin (2011: 157-158) in-depth interviews are a way to collect data or information by meeting directly with informants, with the aim of getting a complete picture of the topic under study. In-depth interviews were conducted with informants including village officials, traditional leaders, religious leaders, and village communities.

The documents used in this study are journals, books, photos, videos, and research results related to the theme of this research. Participation observation is carried out so that researchers can mingle with the subject under study with the aim that researchers are considered part of the society.

Data analysis is carried out simultaneously with the data collection process. Bungin (2011: 144) explains that there are three stages that must be done in analyzing the data, namely data reduction, data presentation, and data verification. These three stages are carried out simultaneously and continuously. The reason for choosing this method is because the researcher will identify, analyze, describe and interpret the phenomena that have been found.

\section{Result}

\subsection{Exploration of the Value Wisdom in Osing Society Life}

The values of local wisdom that exist in the osing society up to now are still held firm and guarded, both in terms of relations with the general public or for private. For example, the tradition of the tumpeng sewu salvation for their osing residents believes that the tradition can keep away from all kinds of diseases and disasters. If the tradition of salvation is abandoned, it will have an adverse effect on the people of Kemiren village, so that the society maintains this tradition to posterity and does not dare to violate it. And also the salvation of tumpeng sewu is done to honor the coming of the Hajj month. In addition, the ethnic of osing has the principle of "weluring ngngandeng adat ... adat nyangkeng agomo". The attachment of a culture to themselves can be seen as a series of models of behavior from humans based on creativity and belief in the necessities of life, which makes the culture of ancestral heritage still maintained up to now. Like the following interview quotation:

"Osing society here especially those who are surrounded when there are neighbors or other people who are building houses that are still in the form of a framework all residents gather in the house being built to help together sincerely, besides if there are people who have gawe, all residents flocked from oil, rice, sugar and others".

From the quotation the interview above, it is explicitly explained that the purpose of mutual cooperation is to help one another. This means that the attitude of the Osing ethnic still towards tradition is still very high. When the researchers were in our location we were welcomed by the local residents. With the hospitality, the people of the village of Kemiren can bring tourists to visit both from overseas and locally such as the following interview excerpt:

"Now this event is almost every day crowded by visitors from abroad, local, students and also the society, starting from just sightseeing, surveys, and finding out about the culture here, meeting village nurses and some doing research such as you". 
From the observations that have been made, the researchers see harmony and familiarity among citizens, this is based on almost all ethnic of the osing people having a very strong family relationship as an example if there are guests they welcome the guests in an easy, true and suggestive way, meaningful in a hurry or hurriedly hurrying to tell or to sit down and give treats so that the three terms mean that they will be very busy in order to be able to entertain their guests kindly, glad to accept it, to ask to sit down and how to be able to give their guests a meal because the guests bring their own blessings and sustenance.

\subsection{Internalization of Local Wisdom Values in Budgeting}

From the various traditions that are followed, researchers can take and conclude that many values of local wisdom are expressed or implied by the informants in this study. As stated by the following traditional figures:

"The tumpeng sewu salvation tradition is believed to be a rescue refuge when this tradition is abandoned, will have a detrimental effect on the Kemiren village society, so residents keep this tradition of tumpeng sewu salvation until hereditary, and this tradition is believed by the society to be able to distance it self from this catastrophe is a form of respect in welcoming the date of the Hajj "

From the interview excerpt above, it is implicitly explained that by holding a tumpeng sewu salvation it is to avoid the people of the ethnic in the village of Kemiren from all kinds of diseases by serving cone-shaped cone with pecel pithik side dishes. Aside from following traditional rituals, researchers also follow the tradition of mepe kasur. This tradition is carried out every month after the Hajj or Dhul-Hijah month in the Islamic calendar and Java. This tradition is an inseparable part of the ritual, ritual of the tumpeng sewu village. If the tumpeng sewu is held at night, then the tradition of mepe kasur is carried out in the morning until noon. The interesting thing about this tradition is that there are hundreds of mattresses that are laid out in bulk and lined up along the village road. This activity starts in the morning until the sun fades. The procedure for drying mattresses in this kemiran village is indeed no different from anywhere else. Mattresses are laid out in front of the house or on the side of the road, under the hot sun. At certain times the mothers will beat the mattress with rattan to remove the dust that is attached. Another uniqueness is that all the mattresses are the same color, black and have red edges. Like quotations from interviews with the following residents:

"The color of the mattress that is available to the public here is indeed distinctive, which is colored by the color of cemeng (black), abyang (red) which means red and cemeng means black. Sweet potato is the language of osing. Kapok mattress which is dried in the sun, the color is at the top and bottom of the black, while the edges are red, this case illustrates the spirit of work and harmony in the household. And the unique thing is that all of the residents' beds are dried in the mass along the road left and right of the Kemiren village"

Parents who marry off their children will definitely give new bedding with the color of brother and sister to the newlywed. The color of the brother (red) is a symbol of the integrity and eternity of the household, while the color of cemeng (black) has the meaning to reject all kinds of distress. So each newlywed couple hopes to avoid the misfortune and the relationship of the household intact with the brother's mattress.

In addition to the tradition of tumpeng sewu salvation and mepe kasur there is a unique tradition and is always done by the osing ethnic people in Kemiren, namely the barong ider bumi tradition. This activity is an osing ethnic traditional ceremony which is held every second day of Eid or more precisely the month of Shawwal. Barong is a mask that describes a scary animal. Barong in the mythology of the osing tribe is believed to be a form of kindness that has the ability to drive out evil spirits. The barong ider earth is also believed by the osing ethnic that in the life of the next year will bring happiness. Like the following interview with a custom article:

"This ancestral traditional ceremony is carried out as a form of gratitude to the Almighty for His Gift which has given prosperity and peace to the villagers. This ceremony is also believed to prevent disease and disaster, residents here believe that barong is paraded by ancestral spirits".

In addition, the Regent of Banyuwangi in his press conference stated:

"This cultural preservation is an effort to keep local wisdom in the area. So that traditions that have been running for decades or even hundreds of years have become a pillar of support in society life."

From the traditions and rituals that have been followed by the researchers it can be concluded that the value of local wisdom "compliance" has graced the life of the osing etnic socieity. Clearly the compliance indexicality 
analysis can be seen in the table below:

Table 1: Compliance Indexicality Analysis

\begin{tabular}{|c|c|c|c|c|}
\hline Stages & Forms & Data & Indexicality & Reflexivity \\
\hline \multirow[t]{3}{*}{$\begin{array}{l}\text { Exploring the value } \\
\text { of compliance }\end{array}$} & $\begin{array}{l}\text { Following the } \\
\text { preparation of the } \\
\text { tumpeng sewu and } \\
\text { the ingredients to be } \\
\text { provided were rice, } \\
\text { chicken, spices, and } \\
\text { coconut in the form } \\
\text { of a cone and also } \\
\text { pecel pithik }\end{array}$ & $\begin{array}{l}\text { Declaration of } \\
\text { traditional leaders 'if } \\
\text { this ritual is } \\
\text { abandoned it will } \\
\text { have a negative } \\
\text { impact on the society } \\
\text { of the Kemiren so } \\
\text { that residents keep } \\
\text { the tradition from } \\
\text { generation to } \\
\text { generation and do not } \\
\text { dare to violate it. }\end{array}$ & $\begin{array}{l}\text { Traditional leaders } \\
\text { explicitly state that } \\
\text { the people of the } \\
\text { osing tribe are } \\
\text { obedient to God, } \\
\text { ancestors, parents, } \\
\text { the government }\end{array}$ & $\begin{array}{l}\text { The meaning of the } \\
\text { tumpeng sewu } \\
\text { tradition is done to } \\
\text { avoid calamity, } \\
\text { reject } \\
\text { reinforcements and } \\
\text { welcome the arrival } \\
\text { of the Hajj month }\end{array}$ \\
\hline & $\begin{array}{l}\text { Following the } \\
\text { tradition of mepe } \\
\text { kasur Equipment that } \\
\text { must be provided is a } \\
\text { black and red } \\
\text { mattress, rattan bat, } \\
\text { buffer. }\end{array}$ & $\begin{array}{l}\text { The statement of the } \\
\text { traditional leaders of } \\
\text { the mepe kasur } \\
\text { tradition is an } \\
\text { inseparable part of } \\
\text { the tumpeng sewu } \\
\text { ritual where people } \\
\text { have to hang } \\
\text { mattresses that are } \\
\text { red and black in the } \\
\text { daytime. }\end{array}$ & $\begin{array}{l}\text { The traditional leader } \\
\text { explicitly explained } \\
\text { that the procession of } \\
\text { the mepe kasur } \\
\text { carried out by the } \\
\text { tribe of the osing tribe } \\
\text { was an order from the } \\
\text { ancestors that their } \\
\text { grandchildren had to } \\
\text { obey. }\end{array}$ & $\begin{array}{l}\text { The meaning of the } \\
\text { mepe kasur ritual of } \\
\text { red and black is a } \\
\text { symbol of work and } \\
\text { harmony, as well as } \\
\text { compliance with his } \\
\text { parents. }\end{array}$ \\
\hline & $\begin{array}{l}\text { Following the } \\
\text { traditional barong } \\
\text { ider bumi ceremony. } \\
\text { Equipment that must } \\
\text { be provided by } \\
\text { barong masks, } \\
\text { barong kendang } \\
\text { musical instruments, } \\
\text { kempling etc., } \\
\text { chicken, coconut and } \\
\text { rice. }\end{array}$ & $\begin{array}{l}\text { The statement of the } \\
\text { Regent of Abdulah } \\
\text { Azwar Anas, the } \\
\text { activity of preserving } \\
\text { this tradition is an } \\
\text { effort to keep local } \\
\text { wisdom in the area. }\end{array}$ & $\begin{array}{l}\text { The Regent explicitly } \\
\text { stated that the } \\
\text { traditional barong } \\
\text { ider ceremony is a } \\
\text { culture of ancestors } \\
\text { who must be guarded, } \\
\text { respected, and also } \\
\text { obeyed }\end{array}$ & $\begin{array}{l}\text { The meaning of } \\
\text { barong ider bumi } \\
\text { activities is a form } \\
\text { of gratitude on a } \\
\text { holy day and also so } \\
\text { that the village of } \\
\text { Kemiren is safe, } \\
\text { peaceful, also given } \\
\text { abundant crops, and } \\
\text { kept away from all } \\
\text { kinds of diseases } \\
\text { and dangers. }\end{array}$ \\
\hline
\end{tabular}

In the life of the osing ethnic people, the value of compliance dominate their lives in budgeting. The results of interviews with the village head as officials in the Kemiren village as stated in the following quote:

Researcher: Ma'am, has the musrembangdes been implemented?

Head of village :If it is official, not yet, maybe in the near future, it will be reviewed again. But last December there was a "village visit".

Researcher: I see, what do you see about the ribs?

Head of village : Tilik dusun is done to find out the proposals that will be submitted and made a priority in the musrembangdes later

Researcher : So can you say that the tilik dusun can be said as non-formal deliberation, ma'am?

Head of Village : Yes, the society of Osing here according to the government, so even though the tilik dusun has been seen or it is easily a discussion, a formal process such as the musrembangdes will continue.

From the interview quotation, the indexicality of compliance was implicitly conveyed by the village head. The meaning of this expression is that the value of compliance with local wisdom is internalized in the development planning process. Where as the meaning of reflexivity from "... but last December there was already a view from tilik dusun ..." shows that with the presence of some of the people of the osing ethnic, they showed 
the value of complience to the meeting invitation delivered by the village head. So that the value of local wisdom is formed from the compliance of the osing ethnic people to leaders and the government.

In addition to the value of compliance wisdom revealed by various ceremonies and traditional traditions, the value of the local wisdom of mutual cooperation is also revealed in the tradition of tumpeng sewu salvation, and also ngopi sepuluh ewu. The traditional of tumpeng sewu is usually held a week before Eid al-Adha. This activity is carried out as a form of gratitude for the sustenance that they have received to God Almighty. Tumpeng sewu means a thousand cone. The salvage process of tumpeng sewu begins with the activity of making rice by mutual cooperation in each house, a cone made in the form of a cone with osing's typical side dish, pecel pithik (grilled chicken mixed with young coconut which has been spiced with spices). Then the cone is placed in front of residents' houses. tumpeng shape of cone has a special meaning, namely as a guide to serving the creator (GOD), while pecel pithik contains a good moral message, namely ngucel - ngucel barang sithik. Which means to invite people to always be grateful and save money. Like quotations from interviews with the following residents:

"Every time a tumpeng sewu salvation event, we osing people in Kemiren village work together to help each other prepare for the needs that will be used in the mass salvation, such as cone, young coconut, grilled chicken and so on, so we can invite visitors to eat together when the tumpeng sewu event was done"

The tumpeng sewu salvation activity begins with the "ngarak barong" program, the barong paraded is a symbol of the Kemiren Village guard. In addition, the society also installed an oncor ajug-ajug (four-legged bamboo torch lamp) which was simultaneously lit by the village elders when the tumpeng sewu program began, and served to illuminate the road. In recent years the fire used to light the torch was taken from natural fires originating from the Mount Ijen crater, namely blue fire. Along with this, the residents of Kemiren village also burned the blarak, along the village road to eliminate all kinds of dangers. Before the joint meal event began, this activity was started by the community with evening prayers in congregation and prayer together. After eating, residents read yusuf letter until midnight at the home of one of the local community leaders. Lontar yusuf that is read is a series of traditions and rituals that tell the story of the journey of the prophet Yusuf a.s

Another unique tradition is Perang Bangkat. Perang Bangkat is a marriage ceremony that is in the osing ethnic society this must be done if the prospective bride is the first child who has an affair with the first child (kemunjilan osing ethnic), as well as the prospective bride is the last child with a last child, or the last child first and vice versa. Although it is called Perang Bangkat, but in this ceremony there is no physical attack. The war meant in this ceremony is a war of arguments that contain advice - advice, this ceremony is packaged as in a drama between the bridegroom as king and the bride as queen. In osing ethnic customs in Kemiren Village, if one of the residents is holding a wedding or circumcision, the volunteers come to help and contribute to the needs needed by the owner. As quoted from the interview with the following traditional elders:

"This osing society in the Kemiren village feels that their mutual cooperation is very high, not only in terms of village development, but this is also seen if one of the residents wants to marry / circumcise his son / daughter, so people happily help start from erecting tents, bringing all the needs of the residents to start from cooking oil, sugar, rice, eggs, etc., sometimes it accumulates in the warehouse of mas. Even though there are those who do not bring something, it is also fine. The people here are aware of the condition and we are never united or quarrel with fellow citizens. "

From the quotation of the interview above, it is explicitly explained that not only in the development of the osing tribal community, they are mutually cooperative, but in social life such as the implementation of the tradition of marriage or circumcision. From the rituals that have been followed by the researchers it can be concluded that the value of local wisdom "mutual cooperation" has graced the life of the osing etnic socieity. Clearly the mutual cooperation indexicality analysis can be seen in the table below: 
Table 2: Indexicality Analysis of Mutual Cooperation

\begin{tabular}{|c|c|c|c|c|}
\hline Stages & Forms & Data & Indexicality & Reflexivity \\
\hline $\begin{array}{l}\text { Exploring the } \\
\text { value of local } \\
\text { wisdom in mutual } \\
\text { cooperation }\end{array}$ & $\begin{array}{l}\text { Following the } \\
\text { preparation of the } \\
\text { tumpeng sewu and the } \\
\text { ingredients to be } \\
\text { provided were rice, } \\
\text { chicken, spices, and } \\
\text { coconut in the form of } \\
\text { a cone and also pecel } \\
\text { pithik }\end{array}$ & $\begin{array}{l}\text { The expression of the } \\
\text { Kemiren Village society } \\
\text { "... we Kemiren villagers } \\
\text { work together to help each } \\
\text { other prepare the needs } \\
\text { that will be used in mass } \\
\text { salvation ..." }\end{array}$ & $\begin{array}{l}\text { Kemiren society } \\
\text { explicitly stated that the } \\
\text { community volunteered } \\
\text { to help fellow citizens to } \\
\text { welcome the tumpeng } \\
\text { sewu program by } \\
\text { preparing a cone in } \\
\text { mutual cooperation. }\end{array}$ & $\begin{array}{l}\text { The meaning of } \\
\text { the tumpeng sewu } \\
\text { tradition is done to } \\
\text { avoid calamity, } \\
\text { reject } \\
\text { reinforcements } \\
\text { and welcome the } \\
\text { arrival of the Hajj } \\
\text { month. }\end{array}$ \\
\hline & $\begin{array}{l}\text { Following the } \\
\text { tradition of perang } \\
\text { bangkat preparation } \\
\text { and materials that } \\
\text { must be available } \\
\text { chicken, vegetable } \\
\text { spoons, pillows, a } \\
\text { chicken egg, one } \\
\text { coconut, one bunch of } \\
\text { bananas, wonco } \\
\text { kinangan, yellow rice } \\
\text { and others. }\end{array}$ & $\begin{array}{l}\text { The customary elders' } \\
\text { expression "This osing } \\
\text { community in the } \\
\text { Kemiren village feels that } \\
\text { their mutual cooperation is } \\
\text { very high, not only in } \\
\text { terms of village } \\
\text { development, but this is } \\
\text { also seen if one of the } \\
\text { residents wants to marry / } \\
\text { circumcise his son / } \\
\text { daughter. help help ..." }\end{array}$ & $\begin{array}{l}\text { Explicitly the traditional } \\
\text { elders stated that some } \\
\text { of the needs needed by } \\
\text { the owner of the } \\
\text { celebration will be borne } \\
\text { in mutual cooperation } \\
\text { by the residents of the } \\
\text { osing community of } \\
\text { Kemiren Village. }\end{array}$ & $\begin{array}{l}\text { The meaning } \\
\text { contained in the } \\
\text { perang bangkat } \\
\text { ceremony is that } \\
\text { the bride and } \\
\text { groom who is } \\
\text { kemunjilan avoid } \\
\text { the ugliness of the } \\
\text { household and also } \\
\text { that the husband is } \\
\text { responsible. }\end{array}$ \\
\hline
\end{tabular}

In the course of observing development activities, the researchers saw firsthand how osing etnich peoples involved in mutual cooperation. The following is an excerpt from the interview with the village secretary who is monitoring the construction of the welcome gate to the village of Kemiren:

Researcher: Sir, if I am allowed to ask, where do the funds used in the development come from, sir?

Secretary :From the APBD mas

Researcher : So the government of the osing ethnic society in Kemiren Village is very concerned by the government, this is evidenced by the many developments that use the APBD, sir?

Secretary : Yes, man, that's how it is

Researchers : : is there self-help from the society isn't there, sir?

Secretary : if self-help in the form of money from the society exists but not much, the society here is self-supporting in the form of mutual cooperation

From the interview quotation implicitly there is a statement or indexicality which states that "self-help in the form of money from the society exists but not much, society here is self-supporting in the form of mutual cooperation". Reflectively it is also implied that the amount of development in the osing ethnic is one form of the government's attention, although not all the development recommendations proposed by the tribes in the Kemiren village have all been realized.

The value of other local wisdom found at the wedding ceremony of Perang Bangkat is the value of honesty. As we know war Perang Bangkat is a war of argument carried out by representatives of prospective brides and grooms. The procedure for carrying out this procession is that the two sides are separated by a piece of cloth. Then the two parties complained of their respective inheritance. The inheritance was taken from supplies as a condition requested by the queen. As quoted from an interview with a traditional elder:

"In this marriage procession, the groom must prepare the requirements requested by the bride, such as mattresses and pillows, white flowers, nginang utensils, wonco jugs, coconuts, vegetable spoons, etc. The groom must have prepared them. Now the groom must show that he is like a responsible man. 
Table 3: Honesty Indexicality Analysis

\begin{tabular}{|c|c|c|c|c|}
\hline Stages & Forms & Data & Indexicality & Reflexivity \\
\hline $\begin{array}{l}\text { Exploring the } \\
\text { Value of Local } \\
\text { Wisdom Honesty }\end{array}$ & $\begin{array}{l}\text { Following the } \\
\text { tradition of perang } \\
\text { bangkat preparation } \\
\text { and materials that } \\
\text { must be available } \\
\text { chicken, vegetable } \\
\text { spoons, pillows, a } \\
\text { chicken egg, one } \\
\text { coconut, one bunch } \\
\text { of bananas, wonco } \\
\text { kinangan, yellow } \\
\text { rice and others }\end{array}$ & $\begin{array}{l}\text { Traditional elders' } \\
\text { expressions "In this } \\
\text { marriage } \\
\text { procession, the } \\
\text { groom must prepare } \\
\text { the requirements } \\
\text { requested by the } \\
\text { bride, such as } \\
\text { mattresses and } \\
\text { pillows, } \\
\text { flowers, nginang } \\
\text { utensils, } \\
\text { jugs, wonco } \\
\text { vegetable spoons, } \\
\text { etc..." }\end{array}$ & $\begin{array}{l}\text { Implicitly, eldest } \\
\text { villages explain that } \\
\text { all the requirements } \\
\text { requested by a } \\
\text { female pengatin } \\
\text { must be there and } \\
\text { there must not be } \\
\text { anyone who forgets } \\
\text { so that the groom's } \\
\text { honesty is expected } \\
\text { to be known. }\end{array}$ & $\begin{array}{l}\text { The meaning } \\
\text { contained in the } \\
\text { perang bangkat } \\
\text { ceremony is that the } \\
\text { bride and groom } \\
\text { who is kemunjilan } \\
\text { avoid the ugliness of } \\
\text { the household and } \\
\text { also so that the } \\
\text { husband } \\
\text { responsible. }\end{array}$ \\
\hline
\end{tabular}

The accountability activity in the style of the osing ethnic society in Kemiren Village based on the results of interviews with the village head is a form of honesty that has been carried out by the leader to his people. Meanwhile in terms of osing society Kemiren Village it self sees that tilik dusun is a routine activity carried out by osing people who have many benefits for the formation of a transparent and clean government. This is as expressed at the following interview:

"As a government leader in Kemiren Village that has been chosen by residents. Every year is directly responsible for all the activities that exist in Kemiren Village to the community. Which in this case is a form of honesty of its leaders to the people ".

"We as osing ethnic in the village of Kemiren feel they are living in peace. Because various activities can run well and transparently."

From the interview quotation above illustrates that there are local values of honesty that have been internalized in the development responsibility for a year. The accountability carried out by the village head of Kemiren is a form of honesty carried out by the leader to the people who have chosen him.

\subsection{Participation of the Osing Tribe in the Process of Budgeting}

The stages in the musrembangdes activities began with the holding of the "village consultation meeting" at the hamlet, RT and RW level. This stage is a preparation that is always done by each village even though there is no system that regulates it. In this activity, all communities individually have the same rights and voice their opinions. This means that the meeting or discussion of the village community is a reflection of the opinion of the community that has not been interfered with by the interests of the authorities. Recommendations obtained during meetings or consultations from the hamlet, neighborhood and RW levels will later be presented at the time of the "Village Observation" where in this activity the main programs are selected and will be made a recommendation material during the village meeting. The following is an excerpt from the interview with the village head:

"If there are recommendations for activities from the residents proposed, we invite all representatives from the Kemiren village, from the village, $R T, R W$, adat elders, religious elders, all villages, youth clubs, BUMDes, etc. and all are very concerned, because this is for mutual interests of the mas, so if there is a definite recommendation, that is what the community wants and after that there will be a Village Reserve. From my observation, the masses of the most suitable people are in Kemiren. But once the community here did not support the activities or attitudes of the village apparatus they did not want to protest but they usually immediately ran away and were not taken for granted, because they might be considered outrageous. 
From the quotation the interview above, the people of the osing ethnic explicitly were very obedient when they made a plan to build a village. This is known from the words "according to" or "manut" which means the same that the tribe osing in the village of Kemiren despite having recommendations that many of them realize the limitations of the budget, the tribe of Osing people never protested when the recommendations were rejected, this was because the citizens strongly believed to village officials whom they have chosen to hold their mandate and carry out their duties.

After all stages in the musrembangdes are completed, the next process is the musrembang in the subdistrict. The deliberations conducted at this sub-district level are to obtain recommendations on the main activities of the village and to approve the program in the sub-district as a basis in the preparation of the City / District Work Unit Unit Work Plan for the coming year. Subdistrict Musrembang has a goal: First, is to discuss and approve the results of the musrembangdes which will be the main development program recommendations at the sub-district level. Second, discuss and establish the main programs in development activities at the sub-district level which are not yet included in the village development program, third, classify the main program of sub-district development that is in accordance with the functions of the District Level Work Unit.

There are several aspects found in the implementation of the development aspects - these aspects are input aspects, aspects of the governance system / mechanism, aspects of output. In governance aspects there are a number of things that need to be considered, firstly mastering the role of the government is because only a few people come as representatives, second, there is still no governance standard or system to determine the main recommendations, so that this results in more opinion strong in the discussion that was used as the basis for determining the main recommendations, and thirdly, there was still no record of recommendations from villages that were not accepted and also the reasons, resulting in the absence of historical records of documents regarding recommendations that had been proposed. The following is an excerpt from an interview with a traditional elder

"When we recommend at the village level, it is advisable to recommend as many programs as possible, but the realization so far has been limited to three priority programs funded, this is due to limited funds, and more strangely old recommendations are not recorded, which means next year we repeat the recommendation again.

If seen from the output aspect of the musrembang activity, it is seen that there is still no historical planning file that led to a repeat of last year's recommendations, besides the absence of historical record files that make substance participation, accountability and transparency lose its meaning, and there is still no system that facilitates planning activities in villages, sub-districts and district levels.

\subsection{Nurut, Guyub, and Jujur, Representation of the Participation of the Osing Ethnic in the Process of Budgeting.}

The Osing Ethnic in the Village of Kemiren Has a life order that describes noble values and has high local characteristics and has the power to achieve life's perfection of happiness and prosperity The following is an excerpt from an interview with the elders of the osing village:

"There are several principles that are held by the osing ethnic, the people according to them, respect for the customs of their ancestors and being maintained until now, for example" Weluring Cooperates with Adat ... Adat Nyangkeng Agomo "means that welding is said to be guarded or in eman - eman don't be violated and we have to respect the custom that exists, bro, we also don't forget about mareng hang kuoso hang duwe dunyo lan sak isine ". Besides that the tribe osing when facing their guests has the principle of "Gupuh, Lungguh, and Suguh", Gupuh means confused and in a hurry how to give a proper welcome ... Lungguh means to let sit and we also show that we are happy with the arrival of guests.... Suguh means we are obliged to give what we have to be offered sincerely and happily welcome these guests"

With the preservation of various kinds of customs and cultures that exist in the tribe of osing, there are several values contained, including: 1) the implementation of the nature of discipline every time customary activities are never changed in time and always carry out in accordance with ancestral teachings and on time. As is the case for the implementation of barong ider activities which are carried out every year on the 2 nd of the Shawwal this has been done for a long time and has been passed down through generations. 2) accuracy is obtained from the batik process, this is because batik activities are a long series of processes and must be done in stages to get good batik results. 3) the emergence of love for the area or locality, this can also be interpreted as obedient to 
the ancestors, because it has implemented and maintained the existing culture in accordance with the rules taught by the ancestors or ancestors. For example the procedure for implementing kebo-keboan is always in accordance with the stages that already exist, the movements in the gandrung dance are always consistent as well as the musical instruments. 4) the emergence of mutual respect, this arises because the culture that has been taught by its creator can survive until now, hence the realization of mutual respect for the creators of art in Banyuwangi even though they are in different places and times in carrying out a traditional ceremony .

From several observations and interviews, it can be concluded that the values of local wisdom found in the Osing Tribe are as follows: First, Mutual Cooperation. Second, Honesty. Third, Guyub or get along well. The fourth is willing to sacrifice. Fifth, friendly. Sixth, Compliance. If a society has been able to form a strong culture or customs, then there will be a high awareness and community togetherness in fighting for common interests, from where it will form full involvement in the budgeting process based on the locality of the osing ethnic.

After carrying out the analysis, there can be found several small theories and one main theory, among others: First, full involvement occurs due to the basis of values of local wisdom has become the core of osing ethnic society in terms of the budgeting process, therefore accountability and transparency run well. Second, full community involvement occurs due to high social awareness and has been created because existing cultural values are maintained and have become the core of community life as a representation of involvement in the budgeting process, and provide benefits such as the realization of transparency and accountability in walking well. Third, in terms of the budgeting process proposed is a manifestation of a collection - a collection of full involvement behavior and high social awareness as the implementation of the absorption of local wisdom values so that they will provide benefits.

\section{Conclusion}

Broadly speaking, the results of this research explain that the Osing ethnic in Kemiren Village, Glagah Sub-district has local wisdom that until now is still very maintained and maintained. The passing of the values of lokan wisdom found in the tribe of osing in the form of mutual cooperation, honesty, mutual or harmonious values, obedience values or according to all representations of the osing community in behaving and will influence the development process. This can be seen in the appreciation of mutual cooperation values, which are involved in development, appreciation of the value of compliance, namely the role in the planning process, namely musrembangdes, appreciation of the value of honesty, which is involved in accountability. With the existence of local wisdom, it is hoped that a model of engagement that is different from other tribes in Indonesia is expected to be considered more effective in realizing development.

The implication is that with regard to the Regional Work Unit (SKPD) in the budgeting process, it must involve the community more by providing more open access to the community. Submission of directed and continuous socialization must continue to be carried out in order to increase community involvement and officials.

\section{References}

Anoegrajekti, Novi. 2000. "Kesenian Osing: Resistensi Budaya Komunitas Pinggir” dalam Kebijakan Kebudayaan di Masa Orde Baru. Jakarta PMB-LIPI.

Anoegrajekti, Novi. 2003. "Identitas dan Siasat Perempuam Gandrung” dalam SRINTHIL, Media Perempuan Multikultural, April No.3.

Anoegrajekti, Novi. 2004. "Pengembangan Gandrung Banyuwangi dalam Rangka Penguatan Aset Budaya dan Industri Wisata”, Laporan Hasil Penelitian Hibah Bersaing. Jakarta. DP2M-DIKTI.

Anoegrajekti, Novi. 2015. Ritual dan Seni Tradisi Osing Membaca Identitas Suara - Suara Lokal. Prosiding Seminar Nasional Folklor dan Kearifan Lokal. Fakultas Sastra Universitas Jember.

Astuti, Sang Ayu Putu Puji, Dewa Gede Wirama, Ni Ketut Rasmini. 2017. Pengaruh Anggaran Yang Ketat Dan Orientasi Waktu Sebagai Pemoderasi Pengaruh Anggaran Partisipatif Pada Senjangan Anggaran. EJournal Ekonomi dan Bisnis Universitas Udayana.

Brownell. 1982. Participating in Budgeting Locus Of Control and Organization Effectiviness. The Accounting Review.56 (4).884-860.

Bungin, Burhan. 2011. Metodologi Penelitian Kualitatif Aktualisasi Metodologis ke Arah Ragam Varian Kontemporer. PT Rajagrafindo. Persada Jakarta. 
Cooper, L. Dan Elliot, J. 2000. Public Paticipation and Social Acceptability in the philipphine EIA process. Journal of Environmental Assessment Policy and Management 2(3), pp 339-367.

Fatchan, Prof, Dr, Drs, H, Achmad. 2015. Metodologi Penelitian Kualitatif Pendekatan Etnografi dan Etnometodologi Untuk Penelitian Ilmu - Ilmu Sosial. Penerbit Ombak Yogyakarta.

Garrison E. J., Brewer, P. C., dan Noreen, E. W. 2006. Akuntansi Manajerial Jilid 1. Edisi 11. (Alih bahasa Hinduan, N.) Jakarta: Penerbit Salemba Empat.

Handayani, Susi, Nel Arianti. 2010. Pengaruh Anggaran Partisipatif Melalui Budaya Organisasi, Gaya Manajemen dan Motivasi Kerja Terhadapa Kinerja Manajerial dan Kepauasan Kerja. Jurnal Riset Akuntansi Vol. 10 No.1.

Hanifah, Suci Indah, Sugeng Praptoyo. 2015. Akuntabilitas Dan Transparansi Pertanggungjawaban Anggaran Pendapatan Belanja Desa (APBDes). Jurnal Riset dan Ilmu Akuntansi Vol. 4. No. 8.

Hasan, Khojanah, Syamsul Bahri. 2016. Kearifan Lokal Refleksi Cerminan Masyarakat Dalam Proses Penyusunan Anggaran. Konferensi Rgional Akuntansi III. Jember.

Junita, Anita. 2016. Sistem Penganggaran Pendapatan dan Belanaja Desa (APBDes) Teratak Buluh Kecamatan Siak Hulu Kabupaten Kampar Tahun 2014. JOM FISIP Oktober Volume 3 No.2.

Laurian, Lucie. 2004. Public Participation in environmental Decision Making:Finding From Communities Facing Toxic Waste Cleanup. Winter.

Mardiasmo. 2004. Akuntansi Sektor Publik. Adi Offset. Jogjakarta.

Moleong, Lexy .J. 2015. Metodologi Penelitian Kualitatif. PT Remaja Rosdakarya. Bandung.

Muhadjir, N. 2000. Metodologi Penelitian Kualitatif. Edisi IV. Yogyakarta. Penerbit Rake Sarasin.

Mulyadi. 2001. Balance Scorecard: Alat Manajemen Konteporer Untuk Pelipatgandaan Kinerja Keuangan Perusahaan. Salemba Empat. Jakarta.

Murgianto, Sal, M, Munardi, A.M. 1990. Seblang dan Gandrung: Dua Bentuk Tari Tradisi di Banyuwangi. Jakarta: Pembinaan Media Kebudayaan.

Narafin. 2000. Penganggaran Perusahaan. Jakarta. Salemba Empat.

Navarro, Zender. 2002. Dezentralization, Participation and Social control of Public Resources: Participatory Budgeting in Porto Alegre, Brazil dalam seminar : Citizen Partisipation in the Contex of Fiscal Decentralization: The Best Practice in Municipal Administration. Tokyo dan Kobe Jepang.

Prasetyo, Whedy. 2012. Perception Of Post Graduate Accounting Students On Semar Spiritual Philosophy In Building Accounting Knowledge. Jurnal Akuntansi Multiparadigma (JAMAL) Volume 3.

Puspito, Peni. 1998. Damarwulan Seni Pertunjukan Rakyat di Kabupaten Banyuwangi di Akhir Abad ke 20. Tesis. Yogyakarta. Universitas Gajahmada.

Scholte, J. 1927. Gandroeng van Banjoewangiei. Djawa, VII.

Sopanah, Ana. 2004. Strategi Penguatan Masyarakat Dalam Pengawasa Proses Penyusunan dan Pelaksanaan APBD Kota Malang. Laporan Hasil Penelitian. MCW dan YAPPIKA.

Sopanah, Ana. 2007. Analisis Anggaran Pendapatan dan Belanja Daerah (APBD) Berpresepektif Gender. Proceding Konferensi Penelitian Akuntansi dan Keuangan Sektor Publik I. Pascasarjana Univesitas Pembangunan Nasional. Surabaya.

Sopanah, Ana. 2008. Model Pengembangan Partisipasi Masyarakat dalam Proses Penyusunan APBD Kota Malang. 
Sopanah, Ana. 2009. Studi Fenomenologis: Menguak Partisipasi Masyarakat Dalam Proses Penyusunan APBD di Kota Malang. Proceding Simposium Nasional Akuntansi 12. Palembang.

Sugiartha, I Putu Teguh, Nyoman Trisna Herawati, Anantawikrama Tungga Atmadja. 2014. Pengaruh Anggaran Partisipatif Terhadap Budgetary Slack Dengan Informasi ASIMETRI Sebagai Pemoderasi Pada Pemerintah Kabupaten Buleleng. E-Journal Akuntansi Universitas Pendidikan Ganesha. Vol 2, No. 1.

Sujadi. 1986. “Asal Usul dan Keadaan Kesenian Gandrung Banyuwangi Dewasa Ini” dalam Sodedarsono (ed.). Kesenian, Bahasa, dan Folklor Jawa. Yogyakarta. Depdikbud.

Sulistiawan, Dedhy., Yeni. Januarsi., dan Liza. Alvia. 2011. Creative Accounting: Mengungkap Manajemen Laba dan Skandal Akuntansi. Penerbit Salemba Empat. Jakarta.

Warsono, Sony,Arif Darmawan, M. Arsyadi Ridha. 2009. Akuntansi Itu Ternyata Logis Dan Mudah. Edisi 2. Asghard Chapter Yogyakarta.

Widyaningsih, Aristanti. 2011. Moderasi Gaya Kepemimpinan Atas Pengaruh Partisipasi Anggaran Terhadap Budgetary Slack. Jurnal Fokus Ekonomi Vol 6 No.1.

Wolbers, Paul, A. 1992. Maintaning Using Identity Through Musical Performance: Seblang and Gandrung on Banyuwangi, East Java, Indonesia. Urbana. Illinois.

Wolbers, Paul, A. 1993. “The Seblang and its Music: Aspect of an East Javanese fertility rite”dalam Performance in Java and Bali: Studies of narrative, theatre, music dan dance. Bernard Arps (eds). Illinois. London. University Of London.

Wulandari, Diana Eka, Ikhsan Budi Riharjo. 2016. Pengaruh Penganggaran Partisipatif Terhadap Kinerja Manajerial Dengan Komitmen Organisasi Dan Gaya Kepemimpinan.

\section{Internet Source:}

www.keuangandesa.com di akses 28 Maret 2017

\section{State Laws and Regulation Source:}

Undang - Undang RI No.32 Tahun 2009 tentang Perlindungan dan Pengelolaan Lingkungan Hidup.

Undang - Undang No. 23 Tahun 2014 tentang Pemerintah Daerah.

Undang - Undang No. 6 Tahun 2014 Bab VIII Pasal 71 - 75 Tentang Keuangan Dan Aset Desa.

Peraturan Pemerintah No. 43 tahun 2014 Bab VI Pasal 90 - 105 tentang Keuangan Desa, Pengalokasian Bersumber dari APBN dan APBD, Penyaluran, Belanja Desa, APBDes, Pelaporan \& Pertanggungjawaban.

Peraturan Pemerintah No. 60 Tahun 2014 dan Peraturan Pemerintah No 22 Tahun 2015 tentang perubahan atas Peraturan Pemerintah No.60 tahun 2014 tentang Dana Desa yang bersumber dari APBN

Permendagri No 113 Tahun 2014 tentang Pengelolaan Keuangan Desa 